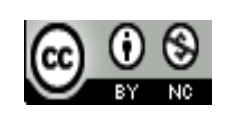

Jurnal Pendidikan Bahasa dan Sastra Indonesia is licensed under

A Creative Commons Attribution-Non Commercial 4.0 International License

\title{
Nilai Sosial Budaya dalam Novel Namaku Teweraut Karya Ani Sekarningsih Pendekatan Antropologi Sastra
}

\author{
Imelda Hutabarat $^{1)}$, Zainal Rafli ${ }^{2)}$, Saifur Rohman ${ }^{3)}$ \\ ${ }^{1)}$ Pendidikan Bahasa, Pascasarjana Universitas Negeri Jakarta \\ E-mail: Imeldahutabaratpb15s2@mahasiswa.unj.ac.id \\ 2) Pendidikan Bahasa, Pascasarjana Universitas Negeri Jakarta \\ E-mail:zainal.rafli@unj.ac.id \\ ${ }^{3)}$ Pendidikan Bahasa, Pascasarjana Universitas Negeri Jakarta \\ E-mail: saifurrohman2000@yahoo.com
}

\begin{abstract}
Abstrak. Tujuan penelitian ini adalah untuk mengidentifikasi tentang nilai sosial budaya dengan pendekatan antropologi yang ditinjau dari kutipan terdapat dalam novel Namaku Teweraut karya Ani Sekarningsih. Penelitian ini adalah penelitian kualitatif deskriptif dengan metode mendeskripsikan data secara mendalam. Data dikumpulkan melalui tahapan pembacaan novel secara seksama, membuat sinopsis, mengklasifikasikan data, menafsirkan hasil analisis data, mengkonfirmasi hasil analisis dan tafsiran kepada ahli satra, dan mendeskripsikan bagian yang telah dianalisis secara terperinci. Analisis dan interpretasi data menunjukkan bahwa: 1) Nilai sosial aspek pengetahuan paling mendominasi, terdapat keberagaman flora, fauna yang ada di suku Asmat. Sifat tokoh utama memberikan pesa moral agar pembaca memiliki watak hidup sederhana, gigih, sabar, berpikir maju, praktis, berpendirian teguh, rajin, cinta lingkungan, cinta tanah air, waspada, rendah hati, peka, cerdas, dan keratif. 2) Nilai sosial aspek sistem organisasi memiliki hubungan, asosiasi, dan kesatuan hidup yang baik di suku Asmat dan dengan suku yang lain. Musyawarah dilakukan sebelum mengadakan upacara, mengambil keputusan, dan menetapkan aturan. 3) nilai sosial aspek religi tidak hanya animisme tetapi suku Asmat menyakini agama kristen. 4) nilai sosial aspek kesenian suku Asmat memiliki kreativitas yang tinggi dalam kesenian,yaitu: seni ukir, seni tari, seni, menyanyi, dan seni musik. Hal tersebut ditunjukkan pada setiap prosesi upacara yang dilakukan.
\end{abstract}

Kata Kunci: nilai sosial budaya; antropologi sastra; novel

\section{PENDAHULUAN}

Novel sebagai media pembelajaran dapat memberikan penilaian tersendiri bagi siswa, baik penilaian dari sisi positif maupun sisi negatif dalam pembelajaran. Terdapat barbagai nilai yang terkadung dalam novel, salah satunya adalah nilai sosial budaya. Pembelajaran lebih bermakna sebab apa yang diajarkan dapat diperlihatkan dalam contoh cerita yaitu lewat pemaparan kisah-kisah dalam novel dan dapat menimbulkan kesan mendalam dengan terlihatnya perubahan pada struktur potensi anak, baik itu pengetahuan, sikap maupun keterampilannya. Inilah poin penting dalam kegiatan pembelajaran, yaitu terjadinya perubahan. Pendapat senada diungkapan oleh Warisman yang menyatakan bahwa salah satu media sastra yang dapat mengembangkan apresiasi siswa yaitu novel. Novel merupakan sebuah prosa naratif fiksional, bentuknya panjang dan kompleks yang menggambarkan secara imajinatif pengalaman manusia. Pengalaman itu digambarkan dalam rangkaian peristiwa yang saling berhubungan dengan melibatkan sejumlah orang (karekter) di dalam setting (latar) yang spesifik. (Warsiman, 2017: 129).

Zukiyah Kolidah (2013) dalam penelitiaanya yang berjudul "Pendidikan Nilai-Nilai Sosial Bagi Anak dan Keluarga Muslim" menyatakan ada beberapa isu mendasar terkait pendidikan yang tidak optimal mengenai nilai sosial anak dalam keluarga. Ini menjadi masalah yang perlu diatasi dalam konteks pendidikan, karena dapat berdampak pada perkembangan anak. Dengan nilai-nilai sosial, perkembangan mental sosial anak dalam keluarga dapat dikembangkan dan ditingkatkan. Pendidikan nilai sosial terintegrasi dalam setiap kegiatan anak, dalam bentuk keterampilan dan kemampuan bertindak individu.

Begitu pentingnya nilai sosial bagi kehidupan tiap individu, nilai sosial berguna sebagai alat pengawas (kontrol) perilaku manusia dengan daya tekan dan daya mengikat tertentu agar orang berperilaku sesuai dengan 
nilai yang dianutnya. Untuk mewujudkan harapan sesuai dengan peranannya. Ketika menghadapi konflik, biasaanya keputusan akan di ambil berdasarkan pertimbangan nilai sosial yang lebih tinggi. Nilai sosial dapat memotivasi seseorang untuk mewujudkan harapan sesuai dengan peranannya.

Penyampaian nilai sosial dalam novel oleh pengarang dapat dilakukan melalui aktivitas tokoh ataupun penutur langsung pengarang. Dalam penuturan langsung, pengarang memberikan penjelasan tentang hal yang baik ataupun hal yang tidak baik secara langsung. Novel memiliki struktur dengan adanya keterkaitan antara bagian-bagian yang membentuk satu kesatuan yang utuh, ada beberapa kutipan analisis menyangkut nilai sosial yang didapat dari novel. Seperti yang terdapat dalam novel Namaku Teweraut karya Ani Sekarningsih. Dalam novel Namaku Teweraut karya Ani Sekarningsih, diceritakan bagaimana sebuah realita kehidupan masyarakat lewat tokoh Teweraut. Novel ini ditulis oleh Ani Sekraningsih yang berlatar antropologi dari rimba rawa Asmat. Novel ini menyajikan realitas imajiner dan kenyataan sehari-hari yang dibaurkan dalam sebuah wisata rohani ke dunia setengah primitif dan dunia supermodern. Petualangan di dua dunia ini dianyam dalam sederet informasi yang sangat menarik.

Menurut Haviland (1999: 29) antropologi adalah studi untuk menyusun sejumlah generalisasi yang bermakna tentang mahluk manusia dan tindakanya serta pengertian yang lengkap tentang keragaman munusia baik kebudayaan maupun ciri fisiknya. Sedangkan Keesing mengatakan bahawa antropologi adalah ilmu yang membicarakan tentang beragam kebudayaan, perbedaan dan persamaan fisik, sifat manusia dan kelembagaannya. Nyoman Kutha Ratna (2011: 152), menyatakan bahwa istilah antroplogi berasal dari bahasa Yunani, yaitu dari asal kata anthropos yang artinya manusia dan logos /logi yang artinya ilmu. Dalam bahasa Indonesia terdiri dari Antro artinya manusia dan $\log o / \log i$ artinya ilmu. Maka sepintas dari arti kata secata etimologi dapat dikatakan bahwa antroplogi adalah ilmu yang mempelajari tentang manusia. Antropologi adalah ilmu yang mempelajari manusia dari segi fisik, psikis, sosial dan budayanya sebagai suatu kesatuan yang menentukan tindakanya.

Unsur kebudayaan dapat dirinci dan dipelajari dengan kategori-kategori sub-unsur dan sub-sub-unsur, yang saling berkait. unsur-unsur yang universal itu terdapat di dalam semua kebudayaan dari semua suku bangsa di manapun di dunia. Kluckhohn (dalam Koentjaningrat, 2009: 222) berpendapat bahwa ada tujuh unsur kebudayaan yang dapat di temukan pada semua bangsa di dunia. Ketujuh unsur dapat disebut sebagai isi pokok dari tiap kebudayaan, yaitu bahasa, sistem pengetahuan, organisasi sosial, sistem perlatan, sistem mata pencaharian, sistem religi, dan kesenian.

Pada penelitian ini akan dibahas mengenai empat unsur dari kebudayaan terbut yang merupakan unsur budaya yang paling mendominasi di suku Asmat.

\section{a) Sistem Pengetahuan}

Sistem pengetahuan berkisar pada pengetahuan tentang kondisi alam sekelilingnya yang meliputi flora dan fauna, ruang pengetahuan tentang alam sekitar, waktu, ruang dan bilangan, sifat-sifat dan tingkah laku sesama manusia serta tubuh manusia. Setiap masyarakat mempunyai sistem pengetahuan yang mungkin berbeda-beda pada setiap masyarakatnya.

\section{b) Organisasi Sosial}

Organisasi sosial merupakan sekelompok masyarakat yang anggotanya merasa satu dengan sesamanya. Sistem kemasyarakatan atau organisasi sosial meliputi kekerabatan, asosiasi, sistem kenegaraan, sistem kesatuan hidup, dan perkumpulan. Setiap masyarakat biasanya memiliki kemasyarakatan, di antaranya, sistem kekerabatan, organisasi politik, sistem hukum, dan sistem pekawinan.

\section{c) Sistem Religi}

Setiap masyarakat memiliki keyakinan terhadap hal-hal bersifat religi, bahkan pada masyarakat atheis (tidak percaya adanya Tuhan) sekali pun. Sistem religi bisa diartikan sebagai sebuah sistem yang terpadu antara keyakinan dan praktik keagamaan yang berhubungan dengan hal-hal yang suci dan tidak dapat dijangkau oleh akal dan pikiran. Sistem religi meliputi sistem kepercayaan, sistem nilai, pandangan hidup, komunikasi keagamaan, dan upacara keagamaan.

\section{d) Kesenian}

Kesenian meliputi baik seni rupa, seni suara, maupun seni lainnya. Secara sederhana kesenian dapat diartikan sebagai segala hasrat manusia terhadap keindahan atau estetika. Bentuk keindahan yang beraneka ragam itu muncul dari sebuah permainan imajinatif dan kreatif. Hal itu dapat memberikan kepuasan batin bagi manusia. Secara garis besar, kita dapat memetakan bentuk kesenian dalam tiga garis besar, yaitu seni rupa, seni suara dan seni tari. Setiap masyarakat mempunyai berbagai macam seni yang tentunya berbeda dengan masyarakat lainnya.

Dari penjelasan tersebut peneliti tertarik mengkaji nilai sosial yang terkandung dalam novel Namaku Teweraut karya Ani Sekarningsih melalui pendekatan antropologi satra karena novel tersebut memiliki karakteristik tersendiri dengan cerita mengenai peradaban suku Asmat yang tinggal di Kabupaten Asmat Papua ini sangat menarik untuk ditelisik. Peneliti juga telah hidup berdampingan dengan masyarakat suku Asmat, sehingga peneliti tertarik untuk menganalisis novel "Namaku Teweraut" kaya Ani Sekarningsih.

Keunikan suku Asmat tak hanya dilihat dari sisi sosial, namum dari sisi budaya juga dapat terlihat bahwa suku ini juga dikenal memiliki tradisi dan adat istiadat yang sangat dipegang teguh. Begitu juga dengan pola hidup masyarakat Asmat yang sangat menghargai alam. Mereka beranggapan bahwa dirinya adalah bagian dari alam. Bahkan, pohon yang tumbuh di sekitar dianggap sebagai gambaran diri. Batang pohon dianggap sebagai gambaran tangan, buah sebagai kepala, dan akar sebagai kaki. Tak mengherankan jika suku Asmat begitu menghormati alam sekitar, mereka masih memegang teguh hukum adat istiadat dari leluhur mereka. Tak lepas dari itu, suku Asmat juga dikenal sebagai 
pengukur sejati, mereka dapat menuangan kreatifitasnya melalui ukira-ukiran nan indah, ukiran kayu tradisional dengan ornamen-ornamen perahu yang menggambarkan wajah nenek moyang, binatang-binatang yang dekat dengan kehidupan masyarakat seperti kasuari, serta motif-motif antropomorfik. Tradisi mengukir itulah yang membawa nama suku Asmat dikenal samapai ke kanca Internasional, di mana setiap tahunnya pada bulan Oktober akan diselenggarakan "Pesta Budaya".

\section{METODE}

Tujuan penelitian ini adalah untuk memperoleh dan mendeskripsikan secara mendalam nilai sosial budaya dalam novel Namaku Teweraut karya Ani Sekarningsih dengan pendekatan antropologi sastra. Nilai sosial yang dianalisis meliputi: nilai sosial aspek pengetahuan, nilai sosial aspek sistem organisasi, nilai sosial aspek religi, dan nilai sosial aspek kesenian. Sumber data dalam penelitian ini adalah kutipan naskah dari novel Namaku Teweraut karya Ani Sekarningsih. Data sekunder dikutip dari buku, jurnal, dan internet sebagai dasar teori untuk menganalisis.

Langkah-langkah yang dilakukan untuk menganalisis data dalam penelitian adalah sebagai berikut: 1) Membaca secara global isi cerita yang terdapat dalam novel; 2) Membuat sinopsis, agar peneliti tidak kehilangan unsur sosiologi sastra yang akan dikaji dalam novel; 3) Membuat catatan-catatan penting yang menunjang kajian dan menandai bagian-bagain novel yang diduga mengandung unsur antropologi sastra yang merujuk dalam setiap dialog atau adegan, dalam novel; 4) Menganalisis klasifikasi data temuan berdasarkan pendekatan antropologi (nilai sosial aspek pengetahuan, nilai sosial aspek sistem organisasi, nilai sosial aspek religi, dan nilai sosial aspek kesenian), 5) Mengaitkan data dengan dengan teori-teori atau pengetahuan yang dimiliki oleh peneliti dengan permasalah dan tujuan penelitian; 6) Menafsirkan hasil analisis data; 7) Mengkonfirmasi hasil analisis dan tafsiran kepada ahli sastra dan ahli antropologi; 8) Mendeskripsikan bagian yang telah dianalisis secara terperinci, dari awal hingga akhir dengan suatu kesimpulan.

\section{HASIL DAN PEMBAHASAN}

Dari hasil penelitian menujukkan bahwa nilai sosial aspek pengetahuan mendominasi dengan total data yang ditemukan 54 data. Selanjutnya, hasil temuan penelitian nilai sosial aspek organisasi masyarakat dengan total 39 data. Kemudian, hasil temuan penelitian nilai kesenian dengan total 38 data dan nilai religi dengan aspek kepercayaan dan ibadah ditemukan dengan total 17 data. Data tersebut menunjukkan bahwa novel "Namaku Teweraut" memberikan nilai sosial aspek pengetahuan mengenai alam, tanah suku Asmat yang meliputi flora, fauna, sifat, ruang, dan waktu yang ada di dalamnya. Hal tersebut dibuktikan dari banyaknya narasi yang menggambarkan flora dan fauna yang merupakan kekayaan alam suku Asmat, yaitu tanah Papua. Dari analisis tersebut juga menunjukkan bahwa nilai sosial dalam aspek pengetahuan, aspek organisasi, aspek religi, dan aspek kesenian dalam novel Namaku Teweraut menunjukkan nilai yang baik karena sesuai dengan nilai-nilai sosial yang berlaku. Berikut hasil analisis dan pembahasan mengenai nilai sosial dalam novel Namaku Teweraut dengan pendekatan antropologi sastra.

\section{A. Nilai Sosial Aspek Sistem Pengetahuan}

Berdasarkan data hasil penelitian nilai sosial aspek pengetahuan ditemukan lima indikator, yaitu indikator alam yang terdiri dari flora dan fauna, indikator sifat, dan indikator ruang dan waktu. Sistem pengetahuan berkisar pada pengetahuan tentang kondisi alam sekelilingnya dan sifat-sifat peralatan yang digunakannya. Sistem pengetahuan meliputi flora dan fauna, ruang pengetahuan tentang alam sekitar, waktu, ruang dan bilangan, sifat-sifat dan tingkah laku sesama manusia serta tubuh manusia. Setiap masyarakat mempunyai sistem pengetahuan yang mungkin berbeda-beda pada setiap masyarakatnya. Kluckhohn (dalam Koentjaningrat, 2009: 222)

Pertama, aspek pengetahuan dengan indikator flora ditemukan sebanyak 13 dan indikator fauna ditemukan sebanyak 10 data. Dari hasil analisis penemuan data menunjukkan bahwa sistem pengetahuan dengan indikator flora dan fauna tersebut merupakan pengetahuan tentang alam suku Asmat yang berada di Irian Jaya atau Papua. Indikator flora dalam novel banyak mengungkapakan mengenai kekayaan tumbuhan yang berada di suku Asmat, seperti pada kutipan berikut:

"Sungai-sungai itu merupakan lorong-lorong yang meliuk-liuk di antara jepitan dinding hutan yang mendongak ke atas, dengan pohonnya berjejal saling beradu. Kaya oleh berbagai jenis gerombolan kayu besi, kayu gaharu, bitanggur, ketapang, kayu susu maupun kayu pala hutan”. (NT, h.6)

Kutipan tersebut mengungkapkan mengenai keberagaman tumbuhan yang ada di alam suku Asmat, yaitu kayu besi, kayu gaharu, kayu ketapang, kayu susu, dan kayu pala hutan. Kekayaan alam dari jenis tumbuhan pohon yang hidup dan tumbuh di alam suku Asmat sangatlah banyak dan beragam jenisnya.

Suku asmat tidaklah menyia-nyiakan tumbuhan yang hidup di sekitanrnya, melainkan memanfaatkan tumbuhan tersebut untuk kebutuhan sehari-hari dan hiasan kepala dan baju ketika upacara pernikahan. Berikut kutipan yang menunjukkan bahwa suku Asmat dapat memanfaatkan kekayaan tumbuhan yang ada di sekitarnya.

"Ah, aku lalu membayangkan diriku mengenakan pakaian terindah dan termewah:awer yang terbuat dari

daun-daun rumbia yang masih segar, kepalaku selain dihiasi kulit kuskus, berhiaskan juga bulubulu burung cenderawasih dan nuri berwarna. Kini di bawah pohon bintang aku menghidupkan kembali cerita nenek". (NT, h. 39)

Kutipan tersebut menunjukkan bahwa suku Asmat dapat manfaatkan kekayaan flora dan fauna yang ada di suku 
Asmat. Pada saat Teweraut akan menikah kepalanya dihias menggunakan kulit kus-kus dan daun rumbia segar, dengan hiasan bulu burung cenderawasih dan nuri berwarna. Kutipan tersebut diperkuat dengan kutipan berikut,

"Kami tidak perlu membayar untuk semua itu. Karena alam sekitar memenuhi kebutuhan kami dengan cumacuma. Lapar? Tinggal menjaring atau menombak. Sagu tinggal memangkur. Umbi-umbian tinggal menggali. Kebutuhan pakaian? Hutan cukup banyak menyediakan pucuk-pucuk rumbia dan sagu, bulubulu burung sebagai hiasan kepala, kalung-kalung kemegahan gigi anjing tinggal memperolehnya dengan mudah sebagai aksesoris yang memperlihatkan penampilan mentereng seseorang". (NT, h. 203)

Kutipan tersebut merupakan ungkapan tokoh utama Teweraut yang menyatakan bahwa kekayaan alam di Papua khususnya di suku Asmat sangatlah berlimpah. Jika lapar, dapat menjaring ikan dan menombak hewan yang ada dalam hutan. Untuk mendapatkan sagu pun mudah karena pohon sagu yang banyak tumbuh dapat diambil dan memangkurnya. Umbian-umbian juga mudah didapatkan hanya dengan menggali tanah. Begitupula dengan kebutuhan pakaian yang diperlukan dapat diperoleh dari flora dan fauna yang ada di alam suku Asmat. Dalam pandangan orang Asmat, hutan menyediakan manfaat yang banyak, untuk mengias kepala dapat menggunakan puncukpuncuk rumbia dan sagu, bulu-bulu burung sebagai hiasan kepala. Menghias kepala dapat menggunakan gigi anjing yang mudah diperoleh. Hal tersebut merupakan aksesoris yang dianggap dapat memperlihatkan penampilan mentereng seseorang di suku Asmat.

Kekayaan alam suku Asmat tersebut memberikan perasaan kagum pada penduduk suku Asmat tersendiri. Berikut kutipan yang menyatakan kekaguman tersebut.

"Betapa para leluhur telah arif menjaga dan meperlakukan hutan dengan ramah. Beratus tahun nenek moyangku tidak lupa menetapkan ketentuan larangan pada daerah-daerah tertentu, yang berbeda satu dengan lainnya. Beratus tahun kami bisa menggunakan kayu untuk membuat perahu-perahu lesung dan rumah dengan sejahtera tanpa melupakan hak dan tanggung jawab yang telah digariskan itu. Sehingga ada kalanya bagiku timbul perasaan kagum mengunjungi hutan yang spesiesnya tanamannya atau satwanya saling berbeda atau unik pesonanya. Hampir semua lelaki Asmat kenal akan jenis pohon yang boleh dan tidak boleh diperlakukan kasar. (NT, h. 203-204)

Kutipan tersebut menyatakan bahwa tokoh utama Teweraut menggagumi hutan suku Asmat di Papua, karena spesies flora dan faunanya yang unik. Pesona keberagaman flora dan fauna memberikan kekaguman tersendiri bagi penduduk suku Asmat dan para pendatang. Kekayaan flora dan fauna tersebut dikenal oleh seluruh lelaki Asmat dan kekayaan flora dan fauna tersebut diperlakukan dengan sangat baik sehingga para penduduk suku Asmat dapat mengetahui jenis pohon yang boleh dan tidak boleh diperlakukan kasar.
Dari kutipan aspek pengetahuan indikator flora dan fauna dapat disimpulkan bahwa indikator flora dan fauna merupakan indikator paling mendominasi yang ditemukan sebanyak 23 data. Indikator flora dan fauna tersebut dibuktikan dengan data yang ditemukan dalam novel dalam tabel analisis data. Indikator flora dan fauna ditemukan pada alam suku Asmat yang kaya dengan tumbuhan berupa pohon dan beranekaragam hewan. Kekayaan alam suku Asmat pada flora dan fauna tersebut dimanfaatkan oleh orang Asmat dengan menggunakannya untuk bahan makanan dan menghias diri. Hal tersebut menunjukkan bahwa nilai sosial aspek pengetahuan dengan indikator flora dan fauna dalam novel Namaku Teweraut baik.

Kedua, aspek pengetahuan dengan indikator ruang ditemukan sebanyak 12 data dan indikator waktu ditemukan sebanyak 7 data. Dari hasil analisis penemuan data menunjukkan bahwa sistem pengetahuan dengan indikator ruang dan waktu yang banyak ditemukan secara satu kesatuan dalam novel "Namaku Teweraut". Indikator ruang dan waktu banyak ditemukan pada kutipan yang menyatakan sejarah Papua, seperti pada kutipan berikut:

"Hal itu juga didorong oleh pengetahuan sejarah. Coba perhatikan ribuan tahun sebelum Masehi, orang Mesir telah mengenal keindahan. Berpakaian pantas dan mengenakan perhiasaan yang terbuat daripada logam emas. Sementara banyak tatanan kehidupan masyarakat terpencil di Irian Jaya pada tahun 2000 ini, terlupakan orang. Mama tak terkendali berpidato panjang". (NT, h. 124)

Kutipan tersebut menjelaskan mengenai sejarah Mesir dan Irian jaya yang berbeda dari ruang dan waktu. Ruang dan waktu yag dibedakan adalah pada ribuan tahun sebelum Masehi orang Mesir telah mengenal keindahan dari segi berpakaian dan perhiasaan emas sedangkan pada tahun 2000 ini masyarakat terpendil di Irian Jaya terlupaka orang dan memiliki tatanan kehidupan yang sangat berbeda dengan yang daerah lainnya. Perbedaan signifikan tersebut disampaikan oleh Mama Rin kepada suku Asmat. Mama Rin mengungkapkan kegelisahan dan mendapatkan perhatian dari pemerintah atas keadaan dan masyarakat terpencil di Irian Jaya.

Begitupula pada kutipan berikut yang menjelaskan mengenai sejarah Papua yang termasuk pada indikator ruang dan waktu.

“Tanggal 17 Agustus 1945 saat Jepang menyerang pada Sekutu setelah Nagasaki dan Hiroshima di bom atom, tentunya sebagai bekas wilayah jajahan Hindia Belanda, Papua pun masuk ke dalam wilayah Indonesia. Tapi pada Konferensi Denpasar 1946 saat membentuk Negara Indonesia Timur, Belanda ternyata memotongnya dari wilayah Indonesia Timur, Belanda ternyata memotongnya dari wilayah Indonesia dan mencaplok Irian sebagai cadangan wilayah pagi para pengungsi Belnda-Indo yang ingin meninggalkan wilayah Republik Indonesia. Sudah tentu Indonesia memperjuangkannya melalui saluran diplomatik untuk merebut Irian kembali dalam wilayah Indonesia". (NT, h. 24) 
Kutipan tersebut menjelaskan mengenai sejarah Papua pada waktu 17 Agustus 1945 yang melingkupi ruang pada saat Jepang menyerang pada Sekutu setelah Nagasaki dan Hiroshima di bom atom, tentunya sebagai bekas wilayah jajahan Hindia Belanda, Papua pun masuk ke dalam wilayah Indonesia. Hal tersebut menjelaskan mengenai sejarah Papua yang merupakan bekas jajahan Hindia Belanda yang diperjuangkan oleh Indonesia untuk direbut kembali melalui saluran diplomatik.

Dari kutipan aspek pengetahuan indikator ruang dan waktu dapat disimpulkan bahwa indikator ruang dan waktu yang ditemukan sebanyak 19 data. Indikator ruang dan waktu tersebut dibuktikan dengan data yang ditemukan dalam novel dalam tabel analisis data. Indikator ruang dan waktu yang ditemukan secara terintegrasi pada satu kutipan, yaitu pada sejarah Papua. Kutipan sejarah Papua tidak bisa dipisahkan dari suku Asmat karena suku Asmat berada di pulau Irian Jaya. Pada narasi sejarah Papua dalam novel Namaku Teweraut terdapat ruang dan waktu yang menjelaskan mengenai kejadian dan peristiwa pada masa terdahulu. Dalam menjelaskan tersebut mendeskripsikan masa saat terjadinya peristiwa tersebut termasuk indikator waktu dan mendeskripsikan mengenai di mana terjadinya dan mencangkup peristiwa tersebut termasuk indikator waktu. Hal tersebut menunjukkan bahwa nilai sosial aspek pengetahuan dengan indikator ruang dan waktu dalam novel Namaku Teweraut baik.

Ketiga, aspek pengetahuan dengan indikator sifat ditemukan sebanyak 12 data. Dari hasil analisis penemuan data menunjukkan bahwa sistem pengetahuan dengan indikator sifat yang banyak ditemukan adalah mengungkapkan berbagai sifat orang Asmat dari berbagai sudut pandang para pendatang dalam novel "Namaku Teweraut". Berikut kutipan mengenai sifat orang Asmat dari sudut pandang tokoh Mama Rin yang merupakan pendatang di suku Asmat.

"Orang-orang Asmat memiliki kepribadian yang teguh, percaya diri, dan perkasa. Kesederhanaan tidak membuatnya rendah diri hingga membatasi ruang gerak. Mereka tampil transparan dengan penuh harga diri dan perasaan bangga. Tanpa canggung dan berpura-pura. Semangat dan gairah mereka telah menjadi satu ungkapan yang nyata sebagai bangsa yang besar penuh percaya diri saat mereka berbaur di tengah gemuruh kemajuan teknologi dan informasi". (NT, 130)

Kutipan tersebut menjelaskan mengenai sifat orang Asmat, dalam sudut pandang Mama Rin sebagai pendatang di suku Asmat bahwa orang Asmat memiliki kepribadian yang teguh, percaya diri, dan perkasa. Hal tersebut dibuktikan dengan kepercayaan yang teguh dan perkasa melakukan segala kegiatan di hutan dalam mencari makan dari tumbuhan dan hewan. Selan itu, orang Asmat juga dinilai orang yang tidak canggung dan berpura-pura. Mereka memiliki semangat dan gairah. Hal tersebut dibuktikkkan dengan orang Asmat yang tidak pantang menyerah dalam belajar walau berada pada daerah tertinggal pada saat kemajuan teknologi dan informasi tersebut.
Pada indikator sifat juga ditemukan penilaian tokoh utama Teweraut terhadap Mama Rin. Teweraut menilai Mama Rin yang sangat ramah ketika pertama kali bertemu, Mama Rin menyodorkan tangannya kepada Teweraut. Bersuara lembut dan manis memberikan kesan baik kepada Teweraut. Berikut kutipan mengenai sifat Mama Rin menurut tokoh utama.

"Tiba-tiba beliau telah berada di depanku, menyodorkan tangannya yang lembut dan putih mulus itu. Kami bersalaman. Lalu beliau menegurku dengan suara halus yang manis. Seakan-akan suara itu meluncur dari awan-awan. Menggetarkan rona kalbuku". (NT, h. 95)

Selain menilai sifat Mama Rin, tokoh utama Teweraut menilai sifat dari suku lain di Papua. Berikut kutipan pada novel Namaku Teweraut mengenai indikator sifat.

"Dengan orang sentani kami merasa seirama. Kelompok mereka mudah mengisi dan saling menyesuaikan dalam acara-acara panggung. Mungkin karena persamaan antara kami yang samasama lahir di dataran rendah rawa-rawa.”. (NT, h. 132)

Kutipan tersebut menyatakan bahwa tokoh utama menilai orang sentani yang cocok dengan kelompok suku Asmat karena orang setani mudah diajak bekerja sama, saling menyesuaikan dalam acara panggung. Teweraut menduga hal tersebut dikarenakan perasaan yang sama karea lahir di dataran redah rawa-rawa.

Dari kutipan aspek pengetahuan indikator sifat dapat disimpulkan bahwa indikator sifat ditemukan sebanyak 12 data. Indikator sifat tersebut dibuktikan dengan data yang ditemukan dalam novel dalam tabel analisis data. Indikator sifat ditemukan pada kutipan perkataan tokoh utama Teweraut terhadap orang lain dan penilian Mama Rin terhadap sifat suku Asmat. Teweraut menilai sifat orang sentani, keluarganya, dan Mama Rin. Pendapat hal tersebut sesuai dengan penelitian Lamsari, Yundi, Hadiyanto (2016) yang menyatakan bahwa pengalaman tokoh dengan sifat dan membuka wawasannya dengan memiliki kemampuan untuk menunjukan perjuangan dalam meraih pendidikan. Mama Rin yang menilai sifat suku Asmat. Kutipan dalam novel mengenai sifat Asmat menyatakan bahwa orang Asmat adalah pekerja keras, memiliki kepribadian yang teguh, percaya diri, dan perkasa. Kesederhanaan orang Asmat dinilai tidak membuatnya rendah diri hingga membatasi ruang gerak. Mereka tampil transparan dengan penuh harga diri dan perasaan bangga, tanpa canggung dan berpura-pura, penuh dengan semangat serta gairah.

Hal tersebut menunjukkan bahwa nilai sosial aspek pengetahuan dengan indikator sifat dalam novel Namaku Teweraut baik.

\section{B. Nilai Sosial Aspek Sistem Organisasi}

Berdasarkan data hasil penelitian nilai sosial aspek sistem organisasi ditemukan empat indikator, yaitu indikator asosiasi, indikator kesatuan hidup, indikator 
kekerabatan, dan indikator perkumpulan. Organisasi sosial merupakan sekelompok masyarakat yang anggotanya merasa satu dengan sesamanya. Sistem kemasyarakatan atau organisasi sosial meliputi kekerabatan, asosiasi, sistem kenegaraan, sistem kesatuan hidup, dan perkumpulan. Setiap masyarakat biasanya memiliki kemasyarakatan, di antaranya, sistem kekerabatan, organisasi politik, sistem hukum, dan sistem pekawinan. Kluckhohn (dalam Koentjaningrat, 2009: 222). Nilai sosial dalam aspek organisasi adalah ukuran baik dan buruk untuk kelompok masyarakat yang meliputi, kekerabatan, asosiasi, sistem kenegaraan, sistem kesatuan hidup dan perkumpulan.

Pertama, aspek organisasi dengan indikator asosiasi ditemukan sebanyak 8 data. Hasil analisis penemuan data menunjukkan bahwa aspek organisasi dengan indikator asosiasi tersebut merupakan kegiatan suku Asmat dalam berkumpul untuk membicarakan dan mendiskusikan suatu masalah. Indikator asosiasi dalam novel Namaku Teweraut banyak mengungkapakan mengenai kegiatan musyawarah dalam suku Asmat, seperti pada kutipan berikut:

Bayimu titisan Teweraut. nDamero Jewecowut nenetapkan penglihatannya. Endew pun menerimanya sebagai suatu penggumuman ketetapan. Seperti layaknya ia mendengar keputusan-keputusan musyawarah oleh para tetua adat. (NT, h. 3)

Kutipan tersebut menyatakan bahwa proses persalinan Endew. Endew adalah ibu kandung tokoh utama, Endew menerima ketetapan yang telah diputuskan oleh ketua adat. Ketetapan yang telah diputuskan oleh ketua adat tersebut diputuskan melalui diskusi dan pembicaraan terlebih dahulu. Hal tersebut menunjukkan bahwa orang Asmat melakukan asosiasi sebelum memutuskan segala sesuatu.

Kedua, aspek organisasi dengan indikator kesatuan hidup ditemukan sebanyak 10 data. Hasil analisis penemuan data menunjukkan bahwa aspek organisasi dengan indikator kesatuan hidup tersebut merupakan kegiatan suku Asmat dalam konsistensi terhadap segala sesuatu. Indikator kesatuan hidup dalam novel banyak mengungkapakan konsistensi orang Asmat dalam mematuhi aturan yang berlaku di suku Asmat, seperti pada kutipan berikut:

Sementara proses persalinan nDiwi berminggu-minggu menjauhi Endew. Kerena tabu seorang suami berada dekat istrinya sewaktu persalinan sewaktu nifas, yang mengandung bencana bagi dirinya, apabila dilangar nDiwi pergi ke ceserasen yaitu sepetak hutan yang dikeramatkan. Untuk memohon kepada para leluhur bagi keselamatan Endew, dan hendaknya dititiskan ndat yuwus yang baik ke alam tubuhku di rahim Endew. (NT, h.4)

Kesatuan hidup yang terdapat pada kutipan tersebut adalah mengenai konsistensi suami di suku Asmat yang tidak boleh medekati istrinya ktika persalinan dan nifas. Konsistensi dalam kesatuan hidup tersebut harus dipatuhi oleh seluruh laki-laki selama istrinya hamil, melahirkan, dan masa nifas. Jikalau tidak dipatuhi maka akan mendatangkan bencana bagi dirinya dan keluarga. Apabila dilangar nDiwi pergi ke sepetak hutan yang dikeramatkan untuk memohon kepada para leluhur bagi keselamatan Endew, dan hendaknya dititiskan ndat yuwus yang baik ke alam tubuhku di rahim Endew.

Ketiga, aspek organisasi dengan indikator kekerabatan ditemukan sebanyak 10 data. Dari hasil analisis penemuan data menunjukkan bahwa sistem organisasi dengan indikator kekerabatan tersebut merupakan penjelasan hubungan dan sistem kekerabatan yang ada di suku Asmat. Indikator kekerabatan dalam novel Namaku Teweraut banyak mengungkapakan mengenai hubungan keakraban dalam sebuah keluaraga di suku Asmat, seperti pada kutipan berikut:

Malam itu amat berkesan. nDiwi dan saudarasaudaranya berada di rumah adat. Nenek masih hidup dan semua lengkap mengelilingi perapian tungku nenek. Aku duduk dipangkuan Endew bersama saudara tiriku omanmok. Kakaku Dawer berbaring menelungkup dekat kaki nenek, menompangkan kepala. Kami membakar juga bola-bola sagu dan ikan belanak sisa makan sore di atas api tungku. Sambil meperhatikan orang mengudap potongan ikan dan potongan sagu bakar, nenekpun bercerita seperti yang pernah dilisankan orang-orang tua padanya. (NT, h. 32)

Kutipan tersebut menjelaskan mengenai kekerabatan antara nenek dan cucunya yang akrab. Mereka makan kudapan potongan ikan dan sagu bakar bersama sambil nenek bercerita mengenai cerita-cerita yang telah diwariskan secara turun menurun dari orang-orang terdahulu. Hal tersebut menunjukkan kekerabatan yang dekat antara nenek dan para cucu dengan duduk, makan, dan bercerita bersama. Kedekatan kekerabatan tersebut memberikan dampak positif bagi hubungan dan kedekatan yang baik secara kekeluargaan.

Sistem kekerabatan dan kekeluarga sangatlah penting di suku Asmat. Kekerabatan tersebut menjadi pemersatu di anatara suku Asmat dengan suku yang lainnya yang ada di papua. Kekerabatan tersebut juga berpengaruh ketika pada proses pernikahan tokoh utama. Berikut kutipan yang menunjukkan aspek kekerabatan.

Dekat pusat api teronggok sejumlah harta pemberian keluarga. Akapits yang menurut Endew, tak ternilai harganya. Semua benda pusat keluarga Akapits diberikan untukku. Enam buah tengkorak kemenangan, tengkorak panglima besar kakak-beradik, kapak batu tua, batu mas kawin dan beliung batu beliung batu yang sudah langka, kirakira dua puluh yuwursis, sedangkan lainnya kalungkalung tisen bercampur ndrek entah berapa banyak, sejumlah ese, facin yang bagus-bagus, awer, tapin, belang rahang buaya turun-temurun tombak-tombak berukir, pakaian terusan, sarung pelakat, sebuah manik, pisau, uang Rp. 50.000, dan masih banyak benda pakai lainnya yang diperoleh.(NT, h. 74).

Kutipan tersebut menunjukkan adat pernikahan pada suku Asmat. Tokoh utama sebagai calon pengantin menerima banyak harta pemberian keluarga Akapits. Ibu dari calon pengantin perempuan sangat senang dan bangga 
karena anaknya telah diberikan banyak harta sebagai tanda pernikahan. Harta pemberian tersebut adalah enam buah tengkorak kemenangan, tengkorak panglima besar kakakberadik, kapak batu tua, batu mas kawin dan beliung batu beliung batu yang sudah langka, kira-kira dua puluh yuwursis, sedangkan lainnya kalung-kalung tisen bercampur ndrek entah berapa banyak, sejumlah ese, facin yang bagus-bagus, awer, tapin, belang rahang buaya turun-temurun tombak-tombak berukir, pakaian terusan, sarung pelakat, sebuah manik, pisau, uang $\mathrm{Rp}$. 50.000 , dan masih banyak benda pakai lainnya yang diperoleh.

Barang pemberian pada saat pernikahan tersebut sesuai dengan status kekeluargaan dan kekerabatan yang ada di suku Asmat. Pemberian tersebut diberikan pada tokoh utama yang merupakan anak dari salah satu kepala suku di Asmat. Oleh karena itu, dari segi pemberian dan perlakuan berbeda dari wanita lain yang dinikahi. Dari penjelasan tersebut dapat disimpulkan kekerabatan dalam suku Asmat sangatlah erat karena dibuktikan dengan adanya hubungan dan penghormatan yang diberikan oleh seseorang kepada kerabat atau orang lain.

Keempat, aspek organisasi dengan indikator perkumpulan ditemukan sebanyak 8 data. Dari hasil analisis penemuan data menunjukkan bahwa aspek organisasi dengan indikator perkumpulan tersebut merupakan. Indikator perkumpulan dalam novel Namaku Teweraut banyak mengungkapakan mengenai kepala uku yang berkumpul bersama dalam mengurus da menetapkan setiap upacara ritus, mengurusi hukum, dan pemerintahan adat, seperti pada kutipan berikut:

nDiwiku adalah orang yang terpandang: kondang sebagai mantan panglima perang pada zamannya.

Beliau juga sebagai ketua klen yang turut mengurusi dan menetapkan setiap jenis upacara ritus, disamping mengurusi hukum, dan pemerintahan adat, sehingga beliau masih mendapat jabatan lain sebagai penasehat adat di rumah adat (NT, h. 11).

Kutipan tersebut menunjukkan bahwa ayah dari tokoh utama merupakan orang yang terpandang di suku Asmat karena mantan panglima perang pada zamannya. Sebagai ketua adat, nDiwi tidak pernah mengambil keputusan sendiri tetapi mengedepankan perkumpulan dalam mengurus dan menetapkan jenis upacara ritus, mengurus hukum, dan pemerintahan adat. Hal tersebut menunjukkan bahwa nDiwi orang yang bijak dan pantas untuk dikagumi dan dihormati oleh banyak orang di suku Asmat.

Dari kutipan tersebut dapat disimpulkan bahwa nilai sosial dalam sistem organisasi menjelaskan mengenai hubungan sosial dalam suku Asmat, mulai dari asosiasi, kekerabatan, kesatuan hidup, dan perkumpulan. Dalam penelitian Insum menjelaskan bahwa tradii kekerabatan di suku Asmat me;iputi tradisi perjodohan dan tradisi pembayaran mas kawin yang disesuaikan dengan latar belakang keluarga wanita ( Insum, 2018: 157-159). Dari pemaparan tersebut dapat diketahui bahwa hubungan sosial yang terbangun dalam novel Namaku Teweraut terbangun mulai meliputi bermusyawarah yang dilakukan dalam keluarga dan keputusan hukum serta adat. Kemudian, kesatuan hidup yang dibina dengan pandangan dan tujuan hidup yang sama dalam suku Asmat. Setelah itu, dijalain dengan hubungan kekerabatan yang erat dalam satu suku Asmat maupun antar suku Asmat dengan perkawinan dengan proses perjodohan dan pembayaran mas kawin. Hal tersebut menjadikan kuatnya persaudaraan dan saling hidup saling berdampingan dengan bermusyawarah dan memutuskan upacara ritus, memutuskan hukum, dan pemerintahan adat Asmat.

\section{Nilai Sosial Aspek Religi}

Berdasarkan data hasil penelitian nilai sosial aspek sistem organisasi ditemukan dua indikator, yaitu indikator kepercayaan dan indikator ibadah. Setiap masyarakat memiliki keyakinan terhadap hal-hal bersifat religi, bahkan pada masyarakat atheis (tidak percaya adanya Tuhan) sekali pun. Sistem religi bisa diartikan sebagai sebuah sistem yang terpadu antara keyakinan dan praktek keagamaan yang berhubungan dengan hal-hal yang suci dan tidak dapat dijangkau oleh akal dan pikiran. Sistem religi meliputi sistem kepercayaan, sistem nilai, pandangan hidup, komunikasi keagamaan, dan upacara keagamaan. Kluckhohn (dalam Koentjaningrat, 2009: 222) Nilai sosial dalam aspek religi adalah ukuran baik dan buruk untuk kelompok masyarakat yang meliputi sistem kepercayaan, sistem nilai pandangan hidup, komunikasi keagamaan, dan upacara keagamaan.

Pertama, aspek religi dengan indikator kepercayaan ditemukan sebanyak 16 data dan indikator ibadah ditemukan 1 data. Dari hasil analisis penemuan data menunjukkan bahwa aspek religi dengan indikator kepercayaan tersebut mendeskripsikan keyakinan orang Asmat terhadap budaya turun menurun dari nenek moyang, seperti pada kutipan berikut:

Orang asmat amat tergantung pada kekuatan gaib, pada roh para leluhurnya melalui serangkaian ritual dan mantra - mantra sebagai ungkapan permohonan kesuburan, dan kebahagian, kesejahteraan, keamanan, kemurahan, dan kebahagiaan. Masyarakat kami percaya apa bila para roh ini diabaikan, bencana dan malapetaka seperti sakit dan kematian mudah dating (NT, h. 54).

Kutipan tersebut menunjukkan kepercayaan orang Asmat terhadap kekuatan gaib, roh para leluhur melalui ritual dan mantra-mantra sebagai doa. Doa tersebut merupakan permohonan untuk kesuburan, kebahagiaan, kesejahteraan, keamanan, kemurahan, dan kebahagiaan. Hal tersebut menunjukkan kepercayaan suku Asmat yang kuat akan roh para leluhurnya. Merka sangat taat dalam menjalankan segala ritual dan menaati segala peraturan yang telah ditetapkan oleh kekuatan gaib dan roh para leluhur. Dengan keyakinan yang kuat tersebut memberikan kekuatan spiritual yang amat kuat juga bago orang Asmat dalam memanjatkan doa dan permohonan. 
Selain itu, orang Asmat juga percaya pada ketetapan yang telah ditentukan oleh roh leluhur. Ketetapan tersebut berupa aturan yang telah dibebankan untuk dijalankan secara turun menurun di suku Asmat. Berikut kutipan mengenai kepercayaan suku Asmat tersebut.

Begitulah, nampaknya sekali mengakarnya hubungan sistem kepercayaan tradisional yang murni sebagai salah satu unsur kebudayaan yang murni dengan tatanan sosial masyarakat, $m B$ is atau ukiran pada alat-alat pakai tradisional tidak ubahnya suatu mediator. Orang asmat percaya, tindakan papisy diawasi seekor ular raksasa dengan cara mencium para pelangar ketentuan adat. Apabila dilanggarnya, tanpa ampun ular itu akan melahap orang yang membangkang. (NT, h. 54).

Kutipan tersebut menunjukkan bahwa kepercayaan orang Asmat sangatlah kuat terhadap aturan-aturan yang berlaku. Atuan tersebut dipatuhi dan diterapkan dalam kehidupan sehari-hari. Orang Asmat percaya tindakan papisy itu diawasi oleh seekor ular raksasa, menghukum para pelanggar aturan dengan cara mencium kaki para pelanggar tersebut. lebih parahnya lagi adalah ular akan melahap orang yang membangkang akan ketentuan dan peraturan-peraturan yang berlaku di suku Asmat.

"Sebagai mahluk insani, orang Asmat belajar dari setiap kejadian di alam sekitarnya, bahwa Sang Maha Pencipta telah melengkapi sarana untuk mempertahankan hidup sebagaimana hewan dengan nalurinya, tumbuh-tumbuhan dengan bijinya. Duri atau racun sekalipun merupakan benteng pertahanan". (NT, h. 53)

Kedua, aspek religi dengan indikator ibadah ditemukan satu data. Dari hasil analisis penemuan data menunjukkan bahwa orang Asmat melakukan ibadah di gereja dengan mengumandangkan nyayian bersama, seperti pada kutipan berikut:

"Pada suatu undangan misa syukuran untuk menyambut Hari Syukuran di gereja Wanita Dermawan, Bismbi yang di Asmat sejak lama menjabat sebagai diakon, memperoleh pakaian seragam pastor setempat serta mendapat tempat duduk terhormat di bagian khusus.

Kami diberi kesempatan mengumandangkan nyayian bersama. Berwujud serangkaian lagu rohani yang memuat kata-kata kerinduan jamaah kasihNya dalam bahasa kami”. (NT, h. 136)

Kutipan tersebut menyatakan bahwa bahwa dalam menyambut hari syukuran di gereja, orang Asmat melakukan ibadah bersama dengan mengumandangkan nyanyian bersama. Nyayian bersama tersebut merupakan serangkaian lagu rohani yang memuat kata-kata keindahan jamaah kasih-Nya dalam bahasa kami. Kegiatan tersebut dilakukan ketika orang Asmat berada di luar negeri. Orang disekitarnya memberikan kesempatan kepada mereka untuk tetap beribadah. Kegiatan beribadah tersebut menunjukkan adanya ketaatan dan kepercayaan orang Asmat terhadap kekuasaan Tuhan yang Maha Kuasa dan Maha menciptakannya segalanya.
Dari kutipan tersebut dapat disimpulkan bahwa nilai sosial aspek religi orang Asmat pada novel Namau Teweraut tersebut menunjukka bahwa orang Asmat percaya akan Tuhan dan roh nenek moyang yang telah terdahulu sehingga orang Asmat melakukan berbagai upacara ritual diiringi dengan nyayian, musik, dan tarian untuk menghormati, meminta izin, dan sebelum melakukan segala sesuatu. Selain percaya, orang Asmat ketika berada di luar kampungnya melakukan kegiatan beribadah kepada Tuhan di gereja. Mereka melakukan hal tersebut dengan menyanyian lagu-lagu rohani untuk memanjatkan kata rinduan mereka atas segala kasih Tuhan. Hal tersebut menunjukkan bahwa suku Asmat memiliki nilai sosial aspek religi yang baik karena memiliki kepercayaan yang penuh kepada Tuhan, roh nenek moyang dan melakukan ibadah dengan upacara dan di gereja. Dengan kepercayaan yang penuh tersebut menjadikan orang Asmat bertindak dan bertingkah laku sesuai dengan aturan adat, kepercayaan roh leluhur dan nenek moyang terdahulu karena mereka percaya ketika melanggar ketentuan dan peraturan tersebut akan mendatangkan bahaya untuk diri sendiri, keluarga, dan orang Asmat.

\section{Nilai Sosial Aspek Kesenian}

Berdasarkan data hasil penelitian nilai sosial aspek sistem organisasi ditemukan empat indikator, yaitu indikator musik, indikator menyanyi, indikator tari, indikator seni ukir dan indikator pertunjukka seni. Kesenian meliputi baik seni rupa, seni suara, maupun seni lainnya. Secara sederhana kesenian dapat diartikan sebagai segala hasrat manusia terhadap keindahan atau estetika. Bentuk keindahan yang beraneka ragam itu muncul dari sebuah permainan imajinatif dan kreatif. Hal itu dapat memberikan kepuasan batin bagi manusia. Secara garis besar, kita dapat memetakan bentuk kesenian dalam tiga garis besar, yaitu seni rupa, seni suara dan seni tari. Setiap masyarakat mempunyai berbagai macam seni yang tentunya berbeda dengan masyarakat lainnya. Kluckhohn (dalam Koentjaningrat, 2009: 222). Nilai sosial dalam aspek kesenian adalah ukuran baik dan buruk untuk kelompok masyarakat yang meliputi seni rupa, seni suara, seni musik, seni ukir, dan seni tari.

Dalam hasil analisis memeberikan tambahan seni yang ada di suku Asmat, yaitu seni rupayang dilakukan adalah seni ukir pada batu dan kayu. Seni suara, yaitu seni musik yang berasal dari alat musik suku Asmat dan nyayiannyayian khas yang ada di suku Asmat. Pertunjukkan seni yang diadakan oleh suku Asmat juga menunjukkan salah satu indikator tambahan juga untuk aspek kesenian.

Pertama, aspek kesenian indikator seni tari ditemukan sebanyak 9 data. Dari hasil analisis penemuan data menunjukkan bahwa aspek kesenian dengan indikator seni tari merupakan kesenian yang sering dilakukan suku Asmat yang berada di Irian Jaya atau Papua. Kesenian tari sering dilakukan dalam upacara-upacara ritual yang digelar dalam suku Asmat. Selai itu, kesenian tari berhubungan erat 
dengan seni musik dan menyanyi. Ketiga kesenian tersebut merupakan satu rangkaian dalam upacara suku Asmat. Berikut salah satu upacara yang meggunakan nyayian daiso dan diiringi dengan tarian pada pacara pernikahan yang, berikut kutipan tersebut:

"Tanpa jeda orang memukul-mukul genderang, menari, menyanyi daiso yang disambut tempik sorak. Membaur dengan lengkingan alat tiup yang menyayat-nyayat langit. (Perlu dijelaskan khusus berkenanaan nyayian daiso. Bentuk nyayian ini sangat dikeramatkan karena susunan kisahnya diyakini orang mengandung tenaga gaib yang sulit untuk diterangkan secara gamblang). (NT, h. 34)

Kutipan tersebut menjelasakan mengenai nyayiannyayian daiso yang dikumpandangkan pada saat upacara. Daiso merupakan nyayian keramat, berupa rintihan kehilangan. Nyayian tersebut dikumandangkan berulangulang tanpa jeda sepanjang jalan menuju pohon yang sudah dipersiapkan untuk membuat patung mBis. Nyayian tersebut sebagai berikut:

"Seitakap, seitakap, kau hilang sirna menyusur Sungai Ayi telah kembali, telah kembaliDemi kami kau kembali". (NT, h. 48)

Kegiatan nyayian, tarian, dan musim tersebut dilakukan secara bersamaan pada upacar tersebut, upacara pembuatan patung $m$ Bis dari kayu yang telah dipersiapkan. Hal tersebut menunjukkan bahwa suku Asmat selalu melakukan kegiatan kesenian dalam setiap upacara yang dilakukan.

Kedua, aspek kesenian indikator seni musik ditemukan sebanyak 8 data. Dari hasil analisis penemuan data menunjukkan bahwa suku Asmat memiliki kreativitas tinggi dalam menciptakan musik dari berbagai alat yang dibuat dan dibentuk sendiri. Dengan memiliki kerativitas tersebut memberikan daya tarik kepada Mama Rin untuk mengekplorasi kesenian suku Asmat. Mama Rin berinisiatif dan membawa perwakilan suku Asmat dan berbagi alat ke luar negeri untuk memperkenalkan kesenian dan kekayaan negara Indonesia akan kesenian tersebut. Berikut kutipan tokoh utama dan teman-temannya mewakili Indonesia untuk mempertunjukkan kesenian suku Asmat.

"Pertunjukan perdana kami mendapat sambutan luas masyarakat Inggris. Para pengunjung sebelum menuju ruang pertunjukkan disambut dalam ruang pamer. Diperkenalkan dengan bentuk-bentuk patung $m B i s$, genderang berukir, patung-patung kawenak, dayung, berbagai jenis tombak, tengkorak berhias dan berbagai motif perisai’. (NT, h. 109-110)

Kutipan tersebut menunjukkan bahwa tokoh utama dan teman-temannya mendapatkan sambutan luas dari masyarakat Inggris saat memperkenalkan dengan bentukbentuk patung $\mathrm{mBis}$, genderang berukir, patung-patung kawenak, dayung, berbagai jenis tombak, tengkorak berhias dan berbagai motif perisai. Pertunjukkan tersebut membuktikan bahwa kretivitas suku Asmat sebagai wakil dari Indonesia mendapatkan respon yang baik di luar negeri.
Ketiga, aspek kesenian indikator seni ukir ditemukan sebanyak 5 data. Dari hasil analisis penemuan data menunjukkan bahwa seni ukir merupakan kemampuan yang harus dimiliki oleh orang Asmat. Namun dalam suku Asmat percaya bahwa semua orang Asmat dapat mengukir kayu tapi tidak semuanya mendapatkan keahlian dan kemampuan untuk mengukir patung $\mathrm{mBis}$, hanya orang-orang terpilihlah yang dapat mengukirnya. Indikator seni ukir dalam novel banyak ditemukan namun ada cerita dibalik patung $m B i s$ yang diagungkan oleh suku Asmat:

" $m$ Bis yang cantik kemudian menikah dan hidup berbahagia dengan pengukir tersebut. namun tak ada sesuatu hal yang terpancang menetap kekal. Sebab pada suatu ketika suaminya berkata: 'Aku ingin mengabadikan kecantikanmu, mBis. Dalam bentuk patung, 'katanya. Berbulan-bulan kemudian Pupurwits pun mengukir, memindahkan kecantikan mBis pada batang tou yang besar, supaya semua orang tahu betapa sesungguhnya cantik mBis baik lahir maupun budi pekertinya". (NT, h. 39)

Kutipan tersebut menunjukkan bahwa mBis merupakan roh leluhur dari suku Asmat yang menikah dan bahagia dengan pengukir namun tidak ada hal yang abadi di dunia ini. oleh karena itu, pengukir tersebut mengabadikan keindahan dan kecantikan istrinya pada batang tou yang besar agar semua orang mengetahui betapa cantiknya mBis baik fisik maupun hatinya.

Keempat, aspek kesenian indikator menyanyi ditemukan sebanyak 4 data. Dari hasil analisis penemuan data menunjukkan bahwa nyayian suku Asmat yang berada di Irian Jaya atau Papua adalah nyanyian yang diciptakan, nyayian rintihan kehilangan yang di nyayian pada setiap prosesi upacara, seperti pada kutipan berikut:

"Mereka juga bergantian menghangatkan udara dengan

kumandang daiso, yakni nyayian keramat untuk melampiaskan pikiran dan perasaan. Pada setiap ujung lagu, debur tabuhan genderang naik menembus langit menggapai-gapai sesuatu yang hilang di balik kerahasiaan langit biru". (NT, h.48)

Kutipan tersebut menyatakan bahwa daiso merupakan nyayian keramat untuk melampiaskan pikiran dan perasaan. Nyayian tersebut dinyayikan dengan diiringi pada setiap ujung lagu, sebur tabuh genderang dan menembus langit menggapai sesuatu yang hilang di balik kerahasiaan langit biru.

Kelima, aspek kesenian indikator pertunjukan seni ditemukan 2 data. Dari hasil analisis penemuan data menunjukkan bahwa pertunjukan seni dengan indikator tersebut merupakan pengetahuan tentang alam suku Asmat yang berada di Irian Jaya atau Papua. Indikator flora dalam novel banyak mengungkapakan mengenai kekayaan tumbuhan yang berada di suku Asmat, seperti pada kutipan berikut:

"Upacara perlombaannya selalu berlangsung meriah. Semua pengukir dari dusun-dusun terjauh datang untuk mengadu kebolehan. Umumnya para tengkulak itu rajin memburu ukiran jauh sampai ke pelosok- 
ang terpencil dan tidak jarang pelosok kampung yang terpencil dan
menemukan kesempatan emas". (NT, 199)

Kutipan tersebut menunjukkan bahwa penyelenggaraan kesenian ukir dalam bentuk perlombaan sering di adakan di kabupaten. Salah satu pesertanya adalah suku Asmat yang berpartisipasi untuk memenagkan perlombaan kesenian ukir tersebut. hal tersebut memerikan kesempatan para tengkulak untuk rajin memburu ukiran jauh sampai ke pelosok-pelosok kampung yang terpencil dan tidak jarang menemukan kesempatan emas.

Dari uraian pembahasan mengenai aspek kesenian tersebut dapat disimpulkan bahwa suku Asmat memiliki kreativitas yang tinggi akan bidang seni. Hal tersebut ditunjukkan dengan adanya berbagai ritual upacara-upacara yang dilaukan di suku Asma, pada upacara tersebut orang Asmat melakukan tarian yang mengikuti musik, dan diiringin nyayian-nyayian yang dilantukan. Ketiga kesenian tersebut merupakan satu kesatuan dan termasuk pada aspek kesenian, yaitu: seni musik, seni menyanyi, dan seni tari.

Begitupula pada kesenian ukir juga ditunjukkan dengan adanya sejarah leluhur suku Asmat seorang pengukir yang mengabadikan istrinya yang cantik fisik dan hatinya pada sebuah patung. Hal tersebut memberikan kepercayaan di suku Asmat, bahwa orang Asmat harus memiliki kemampuan mengukir. Dengan segala kemampuan dan kerativitas orang Asmat dalam berbagai kesenian tersebut memberikan kesempatan suku Asmat untuk mengikuti perlombaan dan pertunjukkan seni yang diadakan kabupaten. Selain itu, membuat Mama Rin tertarik untuk memperkenalkan budaya kesenian suku Asmat pada negara luar negeri.

Dari penjelasan tersebut dapat simpulkan bahwa aspek kesenian dengan indikator seni tari ditemukan sebanyak 9 data, aspek kesenian dengan indikator seni musik ditemukan sebanyak 8 data, aspek kesenian dengan indikator seni ukir ditemukan sebanyak 5 data, aspek kesenian dengan indikator seni menyanyi ditemukan sebanyak 4 data, dan aspek kesenian dengan indikator pertunjukkan seni ditemukan 2 data. Nilai sosial aspek sistem kesenian pada indikator seni tari, indikator seni musik, indikator seni ukir, indikator menyanyi, dan indikator pertunjukan seni dalam novel Namaku Teweraut menunjukkan baik.

\section{SIMPULAN}

Dari hasil analisis nilai sosial dalam novel "Namaku Teweraut" karya Ani Sekarningsih melalui pendekatan antopologi sastra maka, dapat disimpulan sebagai berikut:

1. Nilai sosial aspek pengetahuan dalam novel Namaku Teweraut mengandung banyak pengetahuan alam dengan keberagaman flora, fauna yang ada di suku Asmat, Papua. Begitupula dengan pengetahuan sejarah Papua yang dijelaskan dengan ruang dan waktu yang mendetail. Sejarah mengenai sifat tokoh utama memberikan pesa moral agar pembaca memiliki watak hidup sederhana, gigih, sabar, berpikir maju, praktis, berpendirian teguh, rajin, cinta lingkungan, cinta tanah air, waspada, rendah hati, peka, cerdas, dan keratif. Sifat tersebut merupakan deskripsi sifat orang Asmat yang tidak banyak orang ketahui.

2. Nilai sosial aspek organisasi sosial dalam novel Namaku Teweraut memilki hubungan, asosiasi, dan kesatuan hidup yang baik di suku Asmat dan dengan suku yang lain. Sebelum mengadakan upacara, mengambil keputusan, dan menetapkan aturan, para ketua adat melakukan kegiatan bermusyawarah telebih dahulu. Oleh karena itu, tata tertib di suku Asmat tetap terjaga walaupun tanpa sistem hukum karena orang Asmat mempunyai ketaatan otomatis terhadap adat. Jika terjadi pelanggaran, maka secara otomatis timbul reaksi masyarakat untuk menghukum pelanggar.

3. Nilai sosial aspek religi dalam novel Namaku Teweraut tidak hanya berbau animisme tetapi suku Asmat dalam novel telah mengenal agama kristen. Hal tersebut ditunjukkan dengan berbagai kutipan yang menunjukkan bahwa orang Asmat menggunakan nama baptis, mengenal keuskupan, dan melakukan ibadah di gereja dengan nyayiannyayian rohani.

4. Nilai sosial aspek kesenian dalam novel Namaku Teweraut menunjukkan bahwa suku Asmat memilki kreativitas yang tinggi dalam kesenian,yaitu: seni ukir, seni tari, seni, menyanyi, dan seni musik. Hal tersebut ditunjukkan pada setiap prosesi upacara yang dilakukan, yaitu: upacara mBis, upacara pembuatan patung $\mathrm{mBis}$ upacara menebangan pohon, upacara pernikahan, dan upacara pemakaman.

\section{DAFTAR PUSTAKA}

Djojosuroto, Kinayati. (2006). Analisis Teks Sastra dan Pengajarannya. Yogyakarta: Penerbit Pustaka.

Haviland. J Karel. (1999). Antropologi jilid 1. Surakarta: PT. Gelora Asmara Pratama.

Kholidah, Z. (2013). Pendidikan Nilai-nilai Sosial bagi Anak dalam Keluarga Muslim (Studi Kasus di RT 09 Dukuh Papringan Catur Tunggal Depok Sleman Yogyakarta). Al Hikmah: Jurnal Studi Keislaman, 3(1), 6-6.

Lamasari., Yundi., \& Hadiyanto. (2018). Perjuangan Pendidikan Tokoh Utama dalam Novel Namaku Teweraut karya Ani Sekarningsih. Jambi: Universitas Jambi.

Malawat, I., \& Mofu, H. (2018). TRADISI SUKU ASMAT DALAM ROMAN NAMAKU TEWERAUT KARYA ANI SEKARNINGSIH. RETORIKA: Jurnal Bahasa, Sastra, dan Pengajarannya, 11(2), 154-163.

Ratna, Nyoman Kutha.(2003). Paradigma Sosiologi Sastra. Yogyakarta: Pustaka Pelajar. 
Jurnal Pendidikan Bahasa dan Sastra Indonesia

Volume 4 Nomor 2 September 2019. Page 59-69

p-ISSN: 2477-5932 e-ISSN: 2477-846X

Ratna, Nyoman Kutha.(2008). Teori, Metode, dan Teknik Penelitian Sastra. Yogyakarta: Pustaka Belajar.
Warsiman. (2017). Pengantar Pembelajaran Sastra: Sajian dan Kajian Hasil Riset. Malang: UB Press. 